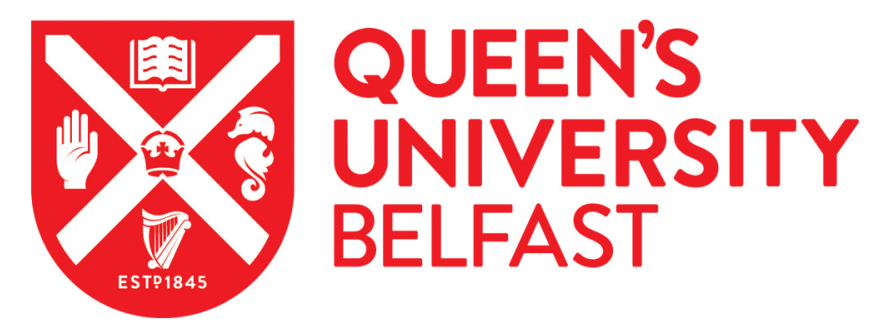

\title{
Transmission of bacteria in bronchiectasis and chronic obstructive pulmonary disease: Low burden of cough aerosols
}

Stockwell, R. E., Chin, M., Johnson, G. R., Wood, M. E., Sherrard, L. J., Ballard, E., O'Rourke, P., Ramsay, K. A., Kidd, T. J., Jabbour, N., Thomson, R. M., Knibbs, L. D., Morawska, L., \& Bell, S. C. (2019). Transmission of bacteria in bronchiectasis and chronic obstructive pulmonary disease: Low burden of cough aerosols. Respirology (Carlton, Vic.). https://doi.org/10.1111/resp.13544

Published in:

Respirology (Carlton, Vic.)

Document Version:

Peer reviewed version

Queen's University Belfast - Research Portal:

Link to publication record in Queen's University Belfast Research Portal

Publisher rights

(C) 2019 Asian Pacific Society of Respirology.

This work is made available online in accordance with the publisher's policies. Please refer to any applicable terms of use of the publisher.

\section{General rights}

Copyright for the publications made accessible via the Queen's University Belfast Research Portal is retained by the author(s) and / or other copyright owners and it is a condition of accessing these publications that users recognise and abide by the legal requirements associated with these rights.

Take down policy

The Research Portal is Queen's institutional repository that provides access to Queen's research output. Every effort has been made to ensure that content in the Research Portal does not infringe any person's rights, or applicable UK laws. If you discover content in the Research Portal that you believe breaches copyright or violates any law, please contact openaccess@qub.ac.uk. 
Transmission of bacteria in bronchiectasis and chronic obstructive pulmonary disease: low burden of cough aerosols.

Rebecca E Stockwell ${ }^{1,2}$, Melanie Chin ${ }^{3}$, Graham R Johnson ${ }^{4}$, Michelle E Wood ${ }^{1,2,3}$, Laura J Sherrard $^{5}$, Emma Ballard ${ }^{6}$, Peter O’Rourke ${ }^{6}$, Kay A Ramsay ${ }^{1,2,7}$, Timothy J Kidd ${ }^{1,8}$, Nassib Jabbour $^{4 \dagger}$, Rachel M Thomson ${ }^{3,9}$, Luke D Knibbs ${ }^{10}$, Lidia Morawska ${ }^{4}$, Scott C Bell*1,2,3.

${ }^{1}$ Lung Bacteria Group, QIMR Berghofer Medical Research Institute, 300 Herston Road, Herston QLD 4006, Australia

${ }^{2}$ Faculty of Medicine, The University of Queensland, Herston QLD 4006, Australia

${ }^{3}$ Department of Thoracic Medicine, The Prince Charles Hospital, 627 Rode Road, Chermside, Brisbane QLD 4032, Australia

${ }^{4}$ International Laboratory for Air Quality and Health, Queensland University of Technology, Brisbane QLD 4000, Australia

${ }^{5}$ Queen's University Belfast, 97 Lisburn Road, Belfast BT9 7BL, United Kingdom

${ }^{6}$ Statistical Support Group, QIMR Berghofer Medical Research Institute, 300 Herston Road, Brisbane QLD 4006, Australia

${ }^{7}$ Department of Biochemistry, University of Otago, 362 Leith Street, North Dunedin 9016, New Zealand

${ }^{8}$ School of Chemistry and Molecular Biosciences, The University of Queensland, St Lucia QLD 4067, Australia

${ }^{9}$ Gallipoli Medical Research Centre, The University of Queensland, Greenslopes QLD 4120, Australia

${ }^{10}$ School of Public Health, The University of Queensland, Herston QLD 4006, Australia 


\section{Email}

rebecca.stockwell@qimrberghofer.edu.au,B.Sc(Hons) (ORCID ID: 0000-0002-0142-7458)

mchin@toh.ca, MD (ORCID ID: 0000-0002-2771-0518)

g.johnson@qut.edu.au, PhD (ORCID ID: 0000-0001-6874-0230)

michelle.wood2@health.qld.gov.au, B.Phty (ORCID ID: 0000-0001-9026-7080)

1.sherrard@qub.ac.uk, PhD (ORCID ID: 0000-0003-3408-1518)

emma.ballard@qimrberghofer.edu.au, PhD (ORCID ID: 0000-0002-9430-2485)

peter.orourke@qimrberghofer.edu.au, PhD (ORCID ID: 0000-0001-9794-2122)

k.ramsay@uq.edu.au,PhD (ORCID ID: 0000-0002-6682-9351)

t.m.kidd@uq.edu.au, PhD (ORCID ID: 0000-0002-6135-6364)

r.thomson@uq.edu.au, MBBS, PhD (ORCID ID: 0000-0003-0686-171X)

1.knibbs@uq.edu.au, PhD (ORCID ID: 0000-0002-0399-2370)

1.morawska@qut.edu.au, PhD (ORCID ID: 0000-0002-0594-9683)

scott.bell@qimrberghofer.edu.au, MBBS, MD (ORCID ID: 0000-0001-8651-7139)

*Corresponding author: Lung Bacteria Group, QIMR Berghofer Medical Research Institute, 300 Herston Road, Herston, Brisbane QLD 4006, Australia.

Tel: +61 73139 4770; Email: scott.bell@qimrberghofer.edu.au

Acknowledgements: The authors wish to express their gratitude to Nassib Jabbour for his enthusiasm and passion over the past four years. We thank Greg Flohr and staff form the Central Pathology Laboratory, Pathology Queensland for microbiological support to the study. We thank the Thoracic Medicine Department at The Prince Charles Hospital in supporting recruitment to the studies. We also thank all the study participants for supporting the work. 
Author contributions: G.R.J., T.J.K., L.D.K., L.M., R.M.T., and S.C.B. conceived and designed the experiment. T.J.K., L.D.K., L.M. and S.C.B. applied for funding. M.C., M.E.W. and S.C.B. recruited the study participants. R.E.S., M.C. and G.R.J. conducted the cough studies. G.R.J. and N.J. acquired the aerosol data. R.E.S, K.A.R. and L.J.S. performed the microbiological analysis. E.L.B led the data analysis. R.E.S. and S.C.B. provide overall responsibility for the data and wrote the manuscript, with input from all co-authors.

Funding support: The project was funded by The Prince Charles Hospital Foundation, Australia (2014-2020). T.J.K. acknowledges National Health and Medical Research Council (NHMRC) Early Career (GNT10884488) and ERS-EU RESPIRE2 Marie Sklodowska-Curie Postdoctoral Research (\#4571-2013) Fellowship support. L.D.K. acknowledges an NHMRC Early Career Fellowship (APP1036620). R.E.S acknowledges The Prince Charles Hospital Foundation and Advance Queensland PhD Scholarships. S.C.B acknowledges Queensland Health Research Fellowship (\#50007). M.C. acknowledges The Ontario Thoracic Society Cameron C Gray Scholarship and CF Canada Fellowship. 


\title{
Summary at a glance
}

Our study shows that people with bronchiectasis and chronic obstructive pulmonary disease (COPD) can release potentially infectious aerosols during coughing; however, no shared stains of Pseudomonas aeruginosa were identified in our study. The results suggest that aerosol transmission is an unlikely mode of cross-infection in people with bronchiectasis and COPD.

\begin{abstract}
Background and objectives: Aerosol transmission of Pseudomonas aeruginosa has been suggested as a possible mode of respiratory infection spread in people with cystic fibrosis (CF); however, whether this occurs in other suppurative lung diseases is unknown. Therefore, we aimed to determine if 1) people with bronchiectasis (unrelated to $\mathrm{CF}$ ) or chronic obstructive pulmonary disease (COPD) can aerosolise $P$. aeruginosa during coughing and 2 ) if genetically indistinguishable (shared) P. aeruginosa strains are present in these disease cohorts.
\end{abstract}

Methods: People with bronchiectasis or COPD and P. aeruginosa respiratory infection were recruited for two studies. Aerosol study: Participants $(\mathrm{n}=20)$ underwent cough testing using validated cough rigs to determine the survival of $P$. aeruginosa aerosols in the air over distance and duration. Genotyping Study: P. aeruginosa sputum isolates (n=95) were genotyped using the iPLEX20SNP platform with a subset subjected to the enterobacterial repetitive intergenic consensus polymerase chain reaction (ERIC-PCR) assay to ascertain their genetic relatedness. Results: Aerosol study: Overall, 7/20 (35\%) participants released P. aeruginosa cough aerosols during at least one of the cough aerosol tests. These cough aerosols remained viable for 4-metres from source and for 15-minutes after coughing. The mean total aerosol count of P. aeruginosa at 2-metres was two colony forming units. Typing study: No shared $P$. aeruginosa strains were identified. 
Conclusions: Low viable count of $P$. aeruginosa cough aerosols and a lack of shared $P$. aeruginosa strains observed suggesting that aerosol transmission of $P$. aeruginosa is an unlikely mode of respiratory infection spread in people with bronchiectasis and COPD.

Key words (five key words in alphabetical order from MeSH list)

Bronchiectasis, chronic obstructive pulmonary disease, Pseudomonas aeruginosa, infection control, person-to-person transmission

Short title (fewer than 40 characters including spaces)

- Infection spread in chronic lung disease

Total word count for the abstract of the manuscript: 250 words

Total word count for the body of the manuscript: 3126 words 


\section{$1 \quad$ List of abbreviations}

\begin{tabular}{|c|c|}
\hline$\%$ & Percentage \\
\hline${ }^{\circ} \mathrm{C}$ & Celsius \\
\hline$\mu \mathrm{g}$ & Microgram \\
\hline $\mathrm{kg}$ & Kilograms \\
\hline $\mathrm{m}$ & Metres \\
\hline $\mathrm{mL}$ & Millilitre \\
\hline $\mathrm{ACI}$ & Andersen cascade impactor \\
\hline BMI & Body mass index \\
\hline $\mathrm{CF}$ & Cystic fibrosis \\
\hline $\mathrm{CFU}$ & Colony forming unit \\
\hline $\mathrm{CI}$ & Confidence interval \\
\hline C. koseri & Citrobacter koseri \\
\hline COPD & Chronic obstructive pulmonary disease \\
\hline E. coli & Escherichia coli \\
\hline ERIC & Enterobacterial repetitive intragenic consensus \\
\hline $\mathrm{FEV}_{1}$ & Forced expiratory volume in one-second \\
\hline FVC & Forced vital capacity \\
\hline GNB & Gram-negative bacteria \\
\hline H. influenzae & Haemophilus influenzae \\
\hline HRCT & High resolution computed tomography \\
\hline HREC & Human Research and Ethics Committee \\
\hline IQR & Inter quartile range \\
\hline MALDI-TOF & Matrix-assisted laser desorption/ionisation-time-of-flight \\
\hline
\end{tabular}




\begin{tabular}{|l|l|}
\hline P. aeruginosa & Pseudomonas aeruginosa \\
\hline PCR & Polymerase chain reaction \\
\hline S. maltophilia & Stenotrophomonas maltophilia \\
\hline SD & Standard deviation \\
\hline SNP & Single nucleotide polymorphism \\
\hline spp. & Species \\
\hline TPCH & The Prince Charles Hospital \\
\hline
\end{tabular}

2 


\section{Introduction}

4 Pseudomonas aeruginosa is an opportunistic pathogen isolated from the sputum of people

5 with underlying lung conditions. In people with cystic fibrosis (CF) over 12 years of age, $P$.

6 aeruginosa is the dominant bacterial pathogen ${ }^{1}$ and cross-infection between people with CF

7 attending specialist centres has been well-documented. ${ }^{2,3}$ The transmission route of

$8 P$. aeruginosa cross-infection has been suggested as aerosol transmission with evidence that

9 viable $P$. aeruginosa (and other CF pathogens) cough aerosols could travel for four metres

10 from the source (person with CF) and remain in the air for 45-minutes after cough ${ }^{4,5}$. Yet,

11 shared strains of $P$. aeruginosa have not been found in environmental sampling, ${ }^{6}$ further

12 supporting aerosol transmission as a possible mode of cross-infection.

14 In (non-CF) bronchiectasis and chronic obstructive pulmonary disease (COPD), $15 P$. aeruginosa predominantly causes infection in those with severe disease ${ }^{7,8}$ and is 16 associated with poorer prognosis ${ }^{9}$, higher mortality ${ }^{10-12}$ and increased hospital admissions ${ }^{13}$.

17 Yet unlike CF, cross-infection with P. aeruginosa is reported to be uncommon in people 18 with bronchiectasis and COPD. ${ }^{14-20}$ Although the evidence for cross-infection is infrequent 19 in non-CF suppurative lung diseases, ${ }^{15,16}$ the transmission mechanism of possible person-to20 person transmission events has not been studied previously. Therefore, we sought to 21 determine if 1) people with bronchiectasis or COPD can produce cough aerosols containing $22 P$. aeruginosa, and 2) if respiratory infections with shared $P$. aeruginosa strains occurs in 23 people with bronchiectasis and COPD attending a centre which is co-located with a large 24 adult CF centre.

\section{Methods}


27 Clinically stable adult participants ( $>18$ years) who had at least one prior $P$. aeruginosa 28 positive sputum culture were recruited from respiratory clinics at The Prince Charles 29 Hospital (TPCH), Brisbane, Australia. Participants with a confirmed diagnosis of 30 bronchiectasis had evidence of consistent radiological changes affecting $\geq 2$ lobes by high 31 resolution computed tomography $[\mathrm{HRCT}]{ }^{21}$ In cases where clinical features and 32 investigations were suggestive, CFTR mutation analysis and sweat electrolytes were 33 performed to exclude a diagnosis of CF. The diagnosis of COPD was based on standard 34 diagnostic criteria including symptoms and physiology. Clinical stability was defined as: no recent change in symptoms and no change in therapy including acute administration of 36 antibiotics in the prior two weeks. Participants in the Aerosol Study were excluded if: 37 clinically unstable and/or experienced recent haemoptysis or pneumothoraces. Written, informed consent was obtained from all participants and the studies were approved by the relevant Human Research and Ethics Committee

(HREC/15/QPCH/29; HREC/11/QPCH/71).

Aerosol study

\section{Cough aerosol sampling}

44 Twenty participants with bronchiectasis $(n=16)$ or COPD $(n=4)$ underwent cough aerosol testing using two validated cough rigs - "distance" and "duration" rigs. ${ }^{4,22}$ Participants

46 performed up to five cough tests: two tests in the distance rig with aerosol collection points at 2- and 4-metres (order randomised), and three tests in the duration rig with aerosol ageing periods of 5-, 15- and 45-minutes. The distance and duration testing methodology have been described in detail previously with participants monitored by a healthcare professional. ${ }^{4,5,22}$ In brief, participants performed respiratory function testing on the day of testing to measure

51 forced expiratory volume in one-second $\left(\mathrm{FEV}_{1}\right)$ and forced vital capacity $(\mathrm{FVC})$ according 
to ATS guidelines. ${ }^{23}$ Weight, height and age were recorded and the percent predicted values calculated from the Global Lung Index. ${ }^{24}$

\section{Distance testing}

For each cough test (2- and 4-metres), participants entered into the "distance" rig, completed 2-minutes of tidal breathing to purge the lungs of room air and then proceeded to cough for 5-minutes at a comfortable pace determined by each study participant. Cough aerosols were extracted continuously during this time using an Andersen Cascade Impactor (ACI) (Thermo Fisher Scientific, USA). The ACI for both distance and duration testing (see below) was loaded with Chocolate-Bacitracin media $(300 \mu \mathrm{g} / \mathrm{mL})$ to determine the viability of $P$. aeruginosa in cough aerosols. ${ }^{4}$

\section{Duration testing}

Participants with COPD were excluded from the duration testing due to airflow obstruction severity. For each test, the remaining bronchiectasis participants completed 2-minutes of tidal breathing to purge the lungs of room air followed by coughing for 2-minutes at a comfortable pace determined by each study participant. The cough aerosols were sealed in the rotating drum inside the duration rig, aged (5-, 15- or 45-minutes) and then extracted using an ACI as previously described. ${ }^{22}$

\section{Microbiology}

Qualitative and quantitative sputum cultures were performed. ${ }^{4,5}$ The aerosol agar plates were incubated aerobically at $37{ }^{\circ} \mathrm{C}$ for 72-hours. Presumptive identification of $P$. aeruginosa isolates was based on positive oxidase reaction and growth at $42{ }^{\circ} \mathrm{C}$. All bacterial isolates had confirmatory identification using matrix-assisted laser 
77 desorption/ionisation-time-of-flight (MALDI-TOF) mass spectrometry and real-time

78 PCR. $^{25}$ Sputum and aerosol $P$. aeruginosa colony forming units (CFU) for individual

79 P. aeruginosa morphotypes were enumerated. The total viable count in sputum $(\mathrm{CFU} / \mathrm{mL})$

80 and total bacterial species aerosol count across the six-stages of the ACI were determined.

81 Participants were defined as low $(<10$ total aerosol CFU) or high $(\geq 10$ total aerosol CFU

82 count) aerosol producers. ${ }^{26}$ A hole-correction factor was applied to account for possible

83 'stacking' of bacterial colonies on the agar plates inside the ACI. ${ }^{27}$ All confirmed

$84 P$. aeruginosa isolates underwent genotyping using an iPLEX20SNP assay (Sequenom) for

85 genotyping as previously published. ${ }^{28}$

86

87 Genotyping Study

Sputum microbiology

Sputa were collected from 30 eligible participants with a recent history of $P$. aeruginosa infection (bronchiectasis, $\mathrm{n}=29 ; \mathrm{COPD}, \mathrm{n}=1$ ) and cultured in an accredited clinical

91 microbiological laboratory in accordance with local protocols (Pathology Queensland).

92 Longitudinal sputum samples were included for analysis where available. Clinical 93 measurements were recorded as detailed above.

\section{Genotyping}

96 Purified presumptive $P$. aeruginosa isolates representing different colonial morphotypes

97 from each specimen (where possible) were selected and stored at $-80{ }^{\circ} \mathrm{C}$, with identification

98 subsequently confirmed by real-time PCR. ${ }^{25}$ All confirmed $P$. aeruginosa isolates

99 underwent iPLEX20SNP genotyping. ${ }^{28}$ The genotyping results were evaluated using a

100 database of multilocus sequence profiles from local environmental, animal, $\mathrm{CF}$ and non-CF

101 associated clinical isolates. ${ }^{6,28}$ Fourteen isolates (from nine participants) had 
102 indistinguishable iPLEX20SNP profiles and subsequently underwent ERIC-PCR analysis ${ }^{29}$

103 (200kb ladder was used for comparison and the gel was run at 80V for 5 hours). ERIC-PCR

104 banding patterns were visually analysed, with isolates showing a variance of $\geq 1$ band

105 allocated to a different rep-PCR type. Furthermore, patterns of infection within-patients

106 were determined. ${ }^{17}$ Clinical records were reviewed to determine possible opportunities for

107 cross-infection such as overlapping hospital admissions, outpatient clinic appointments

108 (including lung function appointments if available) and emergency admissions. During the

109 study period, there were no specific infection control policies to segregate patients with

110 bronchiectasis or COPD from each other or patients with CF when receiving inpatient care,

111 outpatient care or during lung function testing. While the participants with bronchiectasis or

112 COPD recruited to this study may have had contact with patients with $\mathrm{CF}$, we were unable

113 to access specific data to determine if any overlapping contact occurred (and the

114 nature/extent of the contact.

\section{Statistical analysis}

117 Data was analysed using SPSS version 23 (IBM Corp). Categorical variables were

118 summarised as frequency and percentage and continuous variables as mean and standard

119 deviation. The total CFU count present in both sputum and aerosols were log transformed

120 and reported as geometric mean and $95 \%$ confidence interval (CI). The Jeffreys $95 \% \mathrm{CI}$ is

121 given for the proportion of participants with $P$ aeruginosa detected in cough aerosols. A

122 two-tailed Pearson's correlation was used to examine the correlation between the mean

123 concentration of $P$. aeruginosa in the sputum and total mean $P$. aeruginosa aerosol count at

124 2-metre testing. A linear mixed effect model with participant as the random effect and cough

125 test as a fixed effect was used to calculate the overall mean and 95\% CI for the total mean

126 count of Gram-negative bacteria other than P. aeruginosa. Values presented in Table 1 for 
127 the Genotyping Study are from the most recent sputum collection time point with the 128 exception of height and weight. If the height and weight data was missing, the values

129 recorded for the previous collection time point were used in the analysis.

131 Results

\section{Participants}

133 The clinical characteristics of participants in the Aerosol Study $(n=20)$ and the Genotyping

134 Study $(\mathrm{n}=30)$ are summarised in Table 1 . Thirteen participants were enrolled in both the 135 aerosol and genotyping study.

\section{Aerosol study}

138 Sputum samples were obtained from $15(75 \%)$ participants on the cough aerosol sampling testing day (Table 2) (five participants were unproductive). P. aeruginosa was cultured from

$14012(80 \%)$ participants who produced a sputum sample and of these participants, 7 (58\%)

141 produced cough aerosols containing $P$. aeruginosa. The mean concentration of $142 P$. aeruginosa in the sputum was $1.1 \times 10^{7} \mathrm{CFU} / \mathrm{mL}\left(95 \% \mathrm{CI} 0.2 \times 10^{7}\right.$ to $\left.8.0 \times 10^{7}\right)(\mathrm{n}=12)$.

\section{Cough aerosol testing: P. aeruginosa}

145 All 20 participants completed the distance tests of 2- and 4-metres. Sixteen of the

146 participants completed the 5- and 15-minute duration tests, and of these only 10 participants

147 completed the 45-minute duration test. Seven participants (35\%, 95\% CI 17 - 57) produced

148 cough aerosols containing P. aeruginosa during at least one cough tests (Table 2) and also

149 had $P$. aeruginosa detected their sputum sample provided on the day of testing. $P$.

150 aeruginos a positive aerosols were detected in 5/20 (25\%) participants (bronchiectasis, $\mathrm{n}=4$;

151 COPD, $n=1)$ at 2-metres, 4/20 (20\%) bronchiectasis participants only at 4-metres and 2/16 
$152(13 \%)$ bronchiectasis participants only at 15-minutes (Table 2). All participants were 153 considered as low producers ${ }^{26}$ of $P$. aeruginosa cough aerosols with a total mean aerosol 154 count of 2 CFU at 2-metres $(n=5), 3$ CFU at 4-metres $(n=4)$, and 1 CFU at 15 -minutes $(n=2)$

155 (Table 2). No viable $P$. aeruginosa containing aerosols were detected in either the 5-minute

156 test or 45-minute duration tests. The viable burden of potentially infectious aerosols released

157 during coughing was much lower in the bronchiectasis and COPD than we have seen in CF 158 participants. $^{4}$

160 Sputum sampling and cough aerosol testing: $P$. aeruginosa

161 Genotyping of the $P$. aeruginosa cough aerosol isolates revealed genetically 162 indistinguishable $P$. aeruginosa from paired sputum and cough aerosol isolates for the seven 163 participants. One participant had an additional $P$. aeruginosa strain identified in the aerosol

164 cultures that was not detected in the sputum sample. The total viable count of $165 P$. aeruginosa in sputum did not correlate with the total $P$. aeruginosa aerosol count $166 \quad(r=0.416, \mathrm{n}=15, \mathrm{p}=0.12)$ at 2-metres.

167

Sputum sampling: Other Gram-negative bacteria

169 Three (15\%) participants cultured other Gram-negative bacteria (Haemophilus influenzae,

170 Escherichia coli, Stenotrophomonas maltophilia) from the sputum (Table S1,

171 Supplementary Information). The mean concentration of these Gram-negative bacteria in

172 the sputum was $5.8 \times 10^{7} \mathrm{CFU} / \mathrm{mL}\left(95 \%\right.$ CI $\left.0.15 \times 10^{7}-224 \times 10^{7}\right)$ (other GNB sputum 173 counts, $n=4)$. 
176 The three participants that cultured other Gram-negative bacteria from the sputum also had

177 these bacteria recovered from $\geq 3$ of their cough aerosols samples $(H$. influenzae, $\mathrm{n}=2$;

178 E. coli, $\mathrm{n}=1 ;$ S. maltophilia, $\mathrm{n}=1$; Table S1, Supplementary Information); including one

179 participant who also produced cough aerosols with $P$. aeruginosa (Table S1, Supplementary

180 Information). One COPD participant did not provide a sputum sample yet produced

181 Citrobacter koseri and Achromobacter spp. in the cough aerosol samples (Table S1,

182 Supplementary Information). The total mean aerosol count of other Gram-negative bacteria

183 from all distance and duration cough aerosol tests (total=19) was $22(95 \%$ CI 2 - 181).

184

185 Genotyping Study

186 Sputum collection

187 Sixteen (53\%) of the 30 participants provided a single sputum sample. Fourteen (47\%)

188 participants provided multiple sputum samples (two, $\mathrm{n}=10$ participants or three, $\mathrm{n}=4$

189 participants) and the median duration between the initial and final samples was 8.1 months

190 (IQR 2.8 - 45.2) (Figure S1, Supplementary Information). P. aeruginosa sputum isolates

191 were confirmed by PCR.

192

193

Prevalence of shared P. aeruginosa strain infection

194 A total of 95 confirmed $P$. aeruginosa sputum isolates (range: 1 to 8 isolates per participant

195 and 1 to 4 isolates per sample) were genotyped (iPLEX20SNP) (Table S2, Supplementary

196 Information). Of these, 3 isolates were classed as non-typeable. No dominant Australian

197 shared CF P. aeruginosa strains (e.g. AUST-01, AUST-02 and AUST-06) ${ }^{6,28}$ were observed.

198 In contrast, our analysis revealed 20 (67\%) participants had infection with $P$. aeruginosa

199 strains with genotype profiles that showed close genetic relationships to locally-derived

200 genotypes found in the environment, animals and other non-CF clinical presentations. ${ }^{6}$ 
201 There were eight possible transmission events: one overlapping hospital admission of two 202 participants, one overlapping emergency department attendance of two participants and six

203 same day outpatient attendance at TPCH. None of the participants with genetically 204 indistinguishable profiles had likely transmission events (common admissions, emergency 205 department or outpatient attendance). The indistinguishable genotype profiles related to 206 sequence type (ST)-17 (Clone C) (participants 1 and 9), ST-155 (participants 4 and 20), ST207274 (participants 16 and 18) and ST-253 (PA14) (participants 5, 13 and 17). Representative 208 isolates from these participants subsequently underwent ERIC-PCR and no genetically 209 indistinguishable $P$. aeruginosa strains were found between the three sets of pairs or in the 210 group of three participants.

\section{P. aeruginosa infection patterns}

213 Of the 14 participants who had multiple samples analysed, 12 (80\%) harboured a single

214 P. aeruginosa strain over time, one cultured different strains in their sputum over three time 215 points (between 2013 and 2016) and one showed evidence of a new strain then subsequently 216 reverting back to the original strain.

\section{Discussion}

219 Our study demonstrates that people with bronchiectasis and COPD can release aerosols 220 containing viable $P$. aeruginosa during coughing; however, no shared strains of $221 P$. aeruginosa respiratory infection were detected in study participants. Our results support the published data that cross-infection of $P$. aeruginosa affects a minority of people with bronchiectasis $^{14-16}$ and provides much needed evidence to understanding cross-infection in

224 bronchiectasis, which was highlighted as a research priority in a recent review. ${ }^{30}$ Whilst we 225 have demonstrated that aerosol transmission is an unlikely transmission route, it is worth 
226 noting that the participants selected for the study were all low producers ${ }^{26}$ of

227 P. aeruginosa cough aerosols and also, that the study participants had very few opportunities

228 for transmission events to occur during hospital visits; thus reducing the risk of potentially

229 being exposed to each other's cough aerosols.

230

231 The results of our cough aerosol study were in contrast to the results of previous studies in 232 people with CF (Table 2) despite that the participant numbers were almost the same (CF 233 cough study, $n=19^{4}$ versus this study, $n=20$ ). Firstly, only $25 \%$ of all participants in this 234 study produced cough aerosols containing viable $P$. aeruginos $a$ at two-metres whereas most 235 participants with $\mathrm{CF}$ produced cough aerosols containing $P$. aeruginosa at the same 236 distance. ${ }^{4}$ Secondly, the total mean P. aeruginosa aerosol count at 2-metres was much lower 237 in participants with bronchiectasis or COPD compared to people with CF (2 CFU versus 39 238 CFU, respectively) (Table 2). ${ }^{4}$ Thirdly, the distance that viable $P$. aeruginosa cough aerosols 239 could travel in people with bronchiectasis, COPD or $\mathrm{CF}^{4}$ were similar (four-metres); 240 however, the duration that $P$. aeruginosa cough aerosols could remain suspended in the air 241 was shorter in people with bronchiectasis at 15-minutes compared to 45-minutes for people with CF. ${ }^{4}$ Lastly, the mean concentration of $P$. aeruginosa in sputum in the bronchiectasis and COPD cohort did not correlate with the total aerosol count observed at two-metres and this was in contrast to our findings in the CF cough aerosol studies. ${ }^{4,5,31}$

246 Our genotyping study is the first Australian study to investigate the possibility of cross247 infection in people with bronchiectasis and COPD attending a facility which has shared 248 inpatient and outpatient facilities with CF. Our results found that no major Australian CF 249 shared P. aeruginosa strains $^{33}$ were detected in our current cohort. In fact, our study found 250 no evidence of shared $P$. aeruginosa strain infections, which is in keeping with the published 
251 data that shared $P$. aeruginosa strains are uncommon in people with bronchiectasis or

252 COPD. ${ }^{14-17,19,20}$ The $P$. aeruginosa strains detected in our study are commonly found in other

253 niches such as the natural environment and non-CF infections..$^{3,6,14,34}$ Our longitudinal

254 analysis of $P$. aeruginosa isolates showed that the majority of participants retained the same

255 unique $P$. aeruginosa strain over time which is consistent with other recent

256 studies. ${ }^{15,17,19,20,35}$ These results suggest that person-to-person transmission of $P$. aeruginosa

257 is unlikely to occur in people with bronchiectasis and COPD. Instead, P. aeruginosa

258 respiratory infection is likely acquired from the natural environment.

260 Interestingly, our study found four of the 20 participants produced cough aerosols containing 261 other Gram-negative bacteria. This was a higher proportion than in our previous CF $P$. aeruginosa cough aerosol studies ${ }^{4,31,32}$ which is likely to be related to the difference in infection profile in people with bronchiectasis and COPD compared with CF populations. Incidentally, we found two study participants with bronchiectasis who were high producers of H. influenzae cough aerosols, ${ }^{26}$ a common respiratory pathogen of people with bronchiectasis and COPD. ${ }^{36-40}$ Whilst H. influenzae cross-infection is not thought to occur

267 in people with bronchiectasis, ${ }^{18}$ it has been recently reported in a single study of people with

$268 \mathrm{CF}^{41}$ though it is presently unclear if aerosol transmission plays a role in $H$. influenzae acquisition. Our study reported one non-expectorating participant with COPD who produced cough aerosols containing C. koseri and Achromobacter spp. The finding of potentially

271 infectious cough aerosols in the absence of sputum production was also reported in our

272 earlier cough studies in people with $\mathrm{CF}^{4,42}$ yet was in contrast to our two most recent studies in people with CF which found that people with CF who could not expectorate sputum were unable to generate potentially infectious cough aerosols. ${ }^{31,32}$ 
276 This study had several limitations. Firstly, most people with COPD and P. aeruginosa 277 respiratory infection were unsuitable for participation because they had severe airflow 278 obstruction which impacts on the generalisability of our results in these patients. Therefore, 279 a larger study using altered study protocols may better include participants with COPD and 280 may support stronger correlations between clinical and microbiological measures and aerosol CFU counts. Secondly, our sample size was small and the number of participants which produced viable $P$. aeruginosa in their cough aerosols was low. Therefore robust estimates cannot be determined however, the estimates obtained in this study are useful for calculation of sample size for future cough aerosol studies. Similarly, given that the number of participants in the Genotype Study had a median follow-up time of less than 12 months, the diversity of genetic variation of $P$. aeruginosa in patients with bronchiectasis may have also been underestimated. Thirdly, the infectious dose of P. aeruginosa and other Gram-negative bacteria is not known and therefore, the risk of infection from exposure to potentially infectious aerosols remains uncertain. Fourthly, the study participants were tested when clinically stable and therefore, may underestimate the P. aeruginosa aerosols released during pulmonary exacerbations. Fifthly, the media used to capture the cough aerosols was selective for Gram-negative bacteria and thus, the results of this study cannot be generalised to those people with bronchiectasis and COPD harbouring Gram-positive bacterial respiratory infections. Finally, the longitudinal analyses, at times, included one isolate per sputum which limited the capacity to detect strain diversity.

297 Our study has demonstrated that people with bronchiectasis and COPD can release low amounts of viable $P$. aeruginosa aerosols during coughing. The result confirms the finding that $P$. aeruginosa cross-infection is uncommon in bronchiectasis and that aerosol 300 transmission seems unlikely to be a major contributor to P. aeruginosa cross-infection. 
Table 1: Demographics and clinical characteristics of study participants

\begin{tabular}{|c|c|c|}
\hline Patient Characteristics & $\begin{array}{c}\text { Aerosol study } \\
(\mathrm{n}=\mathbf{2 0})\end{array}$ & $\begin{array}{c}\text { Typing study* } \\
(n=30)\end{array}$ \\
\hline Age (years), mean (SD) & $62.5(11.0)$ & $64.0(8.8)$ \\
\hline Sex, male, n (\%) & $6(30 \%)$ & $10(33 \%)$ \\
\hline $\mathrm{FEV}_{1} \%$ predicted, mean (SD) & $56.7(20.7)$ & $58.7(18.1)$ \\
\hline FVC \% predicted, mean (SD) & $76.5(16.6)$ & $75.0(17.0)$ \\
\hline BMI $\left(\mathrm{kg} / \mathrm{m}^{2}\right)$, mean $(\mathrm{SD})$ & $25.3(4.3)$ & $26.7(5.6)^{\wedge}$ \\
\hline \multicolumn{3}{|l|}{ Ethnicity } \\
\hline Caucasian & $19(95 \%)$ & $29(97 \%)$ \\
\hline Asian & $1(5 \%)$ & $1(3 \%)$ \\
\hline \multicolumn{3}{|l|}{ Clinical disease } \\
\hline Bronchiectasis, n (\%) & $16(80 \%)$ & $29(97 \%)$ \\
\hline Idiopathic, n (\%) & $1(6 \%)$ & $10(34 \%)$ \\
\hline Childhood infection, $\mathrm{n}(\%)$ & $14(88 \%)$ & $15(52 \%)$ \\
\hline Pink's Disease, n (\%) & $1(6 \%)$ & $2(7 \%)$ \\
\hline Kartageners Syndrome, n (\%) & $0(0 \%)$ & $1(3 \%)$ \\
\hline Aspiration, n (\%) & $0(0 \%)$ & $1(3 \%)$ \\
\hline COPD, n $(\%)$ & $4(20 \%)$ & $1(3 \%)$ \\
\hline Subjects that contributed multiple sputum samples, n (\%) & $\mathrm{n} / \mathrm{a}$ & $14(47 \%)$ \\
\hline Time under observation (months), median (IQR) & $\mathrm{n} / \mathrm{a}$ & $8.1(2.8-45.2)$ \\
\hline Chronic $P$. aeruginosa infection, n (\%) & $17(85 \%)$ & $25(83 \%)$ \\
\hline \multicolumn{3}{|l|}{ Smoking history } \\
\hline \multicolumn{3}{|l|}{ Bronchiectasis cohort: } \\
\hline Never, n (\%) & $14 / 16(88 \%)$ & $22 / 29(76 \%)$ \\
\hline Former, $\mathrm{n}(\%)$ & $2 / 16(13 \%)$ & $7 / 29(24 \%)$ \\
\hline - $\quad$ Pack years, median (IQR) & $(1,2)^{\sim}$ & $8(2-20)$ \\
\hline \multicolumn{3}{|l|}{ COPD cohort: } \\
\hline Never, n $(\%)$ & $2^{\# / 4}(50 \%)$ & $1 / 1(100 \%)$ \\
\hline Former, $\mathrm{n}(\%)$ & $2 / 4(50)$ & $\mathrm{n} / \mathrm{a}$ \\
\hline - $\quad$ Pack years, median (IQR) & $(45,85)^{\sim}$ & $\mathrm{n} / \mathrm{a}$ \\
\hline
\end{tabular}

${ }^{*} \mathrm{n}=13$ also participated in the Aerosol Study; ${ }^{\wedge} \mathrm{n}=28$; individual pack years; ${ }^{\#}$ One COPD participant had alpha-1 antitrypsin deficiency and the other COPD participant had longstanding asthma); n/a, not applicable. 
Table 2: Comparison of $P$. aeruginosa in sputum and in cough aerosols

\begin{tabular}{|c|c|c|c|c|}
\hline \multirow[b]{2}{*}{ Sputum } & \multicolumn{2}{|r|}{$\begin{array}{c}\text { Participants } \\
\mathrm{n}=20\end{array}$} & \multicolumn{2}{|c|}{$\begin{array}{l}\text { Previously published CF cough study }{ }^{4^{*}} \\
\qquad \mathrm{n}=19^{\sim}\end{array}$} \\
\hline & $\mathrm{n}(\%)$ & CFU/mL, geometric mean $(95 \% \mathrm{CI})$ & $\mathrm{n}(\%)$ & CFU/mL, geometric mean (SD) \\
\hline $\begin{array}{l}\text { Sputum provided } \\
-\quad \text { All participants } \\
\circ \text { Bronchiectasis } \\
\circ \text { COPD }\end{array}$ & $\begin{array}{c}15(75) \\
14 / 16(88) \\
1 / 4(25)\end{array}$ & & $18(95)$ & \\
\hline $\begin{array}{l}\text { P. aeruginosa detected in sputum } \\
\text { - All participants } \\
\circ \text { Bronchiectasis } \\
\circ \text { COPD }\end{array}$ & $\begin{array}{c}12^{\wedge} / 15(80) \\
11 / 14(79) \\
1 / 1(100)\end{array}$ & $1.1 \times 10^{7}\left(0.2 \times 10^{7}-8.0 \times 10^{7}\right)$ & $18 / 18(100)$ & $13.7 \times 10^{7}\left(2.2 \times 10^{7}-106.0 \times 10^{7}\right)$ \\
\hline Cough aerosol & & Count $(\mathrm{CFU})$, geometric mean $(95 \% \mathrm{CI})$ & & Count (CFU), geometric mean $(95 \% \mathrm{CI})$ \\
\hline $\begin{array}{l}\text { P. aeruginosa detected in cough aerosol } \\
\circ \text { All participants } \\
\circ \text { Bronchiectasis } \\
\circ \text { - COPD }\end{array}$ & $\begin{array}{c}7 / 20(35) \\
6 / 16(38) \\
1 / 4(25)\end{array}$ & (2) & $\begin{array}{c}18 / 18(100) \\
- \\
-\end{array}$ & $\begin{array}{l}- \\
- \\
-\end{array}$ \\
\hline $\begin{array}{l}\text { Distance } \\
-\quad \text { 2-metres } \\
-\quad 4 \text {-metres }\end{array}$ & $\begin{array}{l}5^{\wedge} / 20(25) \\
4^{\wedge} / 20(20)\end{array}$ & $\begin{array}{l}2(1-7) \\
3(1-9)\end{array}$ & $\begin{array}{l}17 / 18(94) \\
17 / 18(94)\end{array}$ & $\begin{array}{l}39(30-51) \\
26(20-34)\end{array}$ \\
\hline $\begin{array}{l}\text { Duration } \\
-\quad 5 \text {-minutes } \\
-\quad 15 \text {-minutes } \\
-\quad 45 \text {-minutes }\end{array}$ & $\begin{array}{c}0 / 16(0) \\
2^{\wedge} / 16(13) \\
0 / 10(0)\end{array}$ & $\begin{array}{c}0 \\
1(-1-31) \\
0\end{array}$ & $\begin{array}{l}15 / 18(83) \\
14 / 18(78) \\
14 / 18(78)\end{array}$ & $\begin{array}{l}15(11-20) \\
12(9-16) \\
8(6-11)\end{array}$ \\
\hline
\end{tabular}

$\mathrm{CF}$, cystic fibrosis; CFU, colony forming unit; $\mathrm{mL}$, millilitre; $\mathrm{CI}$, confidence interval; COPD, chronic obstructive pulmonary disease; ${ }^{\text {includes cough }}$

swab from one participant; $\wedge$ numerator represents the number of participants included in the geometric mean calculations; * data taken from Knibbs et al ${ }^{4}$

online supplement, table S3. 


\section{References}

$1 \quad$ Cystic Fibrosis Australia. Cystic fibrosis in Australia 2014: 17th annual report Australian Cystic Fibrosis Data Registry. Australia CF, Sydney, 2016.

2 Parkins MD, Somayaji R, Waters VJ. Epidemiology, biology, and impact of clonal Pseudomonas aeruginosa infections in cystic fibrosis. Clin Microbiol Rev. 2018; 31.

3 Kidd TJ, Soares Magalhaes RJ, Paynter S, Bell SC. The social network of cystic fibrosis centre care and shared Pseudomonas aeruginosa strain infection: a cross-sectional analysis. Lancet Respir Med. 2015; 3: 640-50.

4 Knibbs LD, Johnson GR, Kidd TJ, Cheney J, Grimwood K, Kattenbelt JA, O'Rourke PK, Ramsay KA, Sly PD, Wainwright CE, Wood ME, Morawska L, Bell SC. Viability of Pseudomonas aeruginosa in cough aerosols generated by persons with cystic fibrosis. Thorax. 2014; 69: 740-5.

5 Wood ME, Stockwell RE, Johnson GR, Ramsay KA, Sherrard LJ, Kidd TJ, Cheney J, Ballard EL, O'Rourke P, Jabbour N, Wainwright CE, Knibbs LD, Sly PD, Morawska L, Bell SC. Cystic fibrosis pathogens survive for extended periods within cough-generated droplet nuclei. Thorax. 2018; 10.1136/thoraxjnl-2018-211567.

6 Kidd TJ, Ritchie SR, Ramsay KA, Grimwood K, Bell SC, Rainey PB. Pseudomonas aeruginosa exhibits frequent recombination, but only a limited association between genotype and ecological setting. PLoS One. 2012; 7: e44199.

$7 \quad$ Larsen MV, Janner JH, Nielsen SD, Friis-Moller A, Ringbaek T, Lange P. Bacteriology in acute exacerbation of chronic obstructive pulmonary disease in patients admitted to hospital. Scand J Infect Dis. 2009; 41: 26-32.

8 Evans SA, Turner SM, Bosch BJ, Hardy CC, Woodhead MA. Lung function in bronchiectasis: the influence of Pseudomonas aeruginosa. Eur Respir J. 1996; 9: 1601-4. 9 Loebinger MR, Wells AU, Hansell DM, Chinyanganya N, Devaraj A, Meister M, Wilson R. Mortality in bronchiectasis: a long-term study assessing the factors influencing survival. Eur Respir J. 2009; 34: 843-9.

10 Finch S, McDonnell MJ, Abo-Leyah H, Aliberti S, Chalmers JD. A comprehensive analysis of the impact of Pseudomonas aeruginosa colonization on prognosis in adult bronchiectasis. Ann Am Thorac Soc. 2015; 12: 1602-11.

11 Almagro P, Salvado M, Garcia-Vidal C, Rodriguez-Carballeira M, Cuchi E, Torres J, Heredia JL. Pseudomonas aeruginosa and mortality after hospital admission for chronic obstructive pulmonary disease. Respiration. 2012; 84: 36-43.

12 Boixeda R, Almagro P, Diez-Manglano J, Cabrera FJ, Recio J, Martin-Garrido I, Soriano JB. Bacterial flora in the sputum and comorbidity in patients with acute exacerbations of COPD. Int J Chron Obstruct Pulmon Dis. 2015; 10: 2581-91.

13 McDonnell MJ, Jary HR, Perry A, MacFarlane JG, Hester KL, Small T, Molyneux C, Perry JD, Walton KE, De Soyza A. Non cystic fibrosis bronchiectasis: a longitudinal retrospective observational cohort study of Pseudomonas persistence and resistance. Respir Med. 2015; 109: 716-26.

14 Hilliam Y, Moore MP, Lamont IL, Bilton D, Haworth CS, Foweraker J, Walshaw MJ, Williams D, Fothergill JL, De Soyza A, Winstanley C. Pseudomonas aeruginosa adaptation and diversification in the non-cystic fibrosis bronchiectasis lung. Eur Respir J. 2017; 49. 15 De Soyza A, Perry A, Hall AJ, Sunny SS, Walton KE, Mustafa N, Turton J, Kenna DT, Winstanley C. Molecular epidemiological analysis suggests cross-infection with Pseudomonas aeruginosa is rare in non-cystic fibrosis bronchiectasis. Eur Respir J. 2014; 43: 900-3.

16 Mitchelmore PJ, Randall J, Bull MJ, Moore KA, O'Neill PA, Paszkiewicz K, Mahenthiralingam E, Scotton CJ, Sheldon CD, Withers NJ, Brown AR. Molecular 
epidemiology of Pseudomonas aeruginosa in an unsegregated bronchiectasis cohort sharing hospital facilities with a cystic fibrosis cohort. Thorax. 2017; 10.1136/thoraxjnl-2016209889.

17 Woo TE, Lim R, Surette MG, Waddell B, Bowron JC, Somayaji R, Duong J, Mody $\mathrm{CH}$, Rabin HR, Storey DG, Parkins MD. Epidemiology and natural history of Pseudomonas aeruginosa airway infections in non-cystic fibrosis bronchiectasis. ERJ Open Res. 2018; 4. 18 Mitchelmore P, Wilson C, Hettle D. Risk of bacterial transmission in bronchiectasis outpatient clinics. Curr Pulmonol Rep. 2018; 10.1007/s13665-018-0203-6.

19 Gallego M, Pomares X, Espasa M, Castaner E, Sole M, Suarez D, Monso E, Monton C. Pseudomonas aeruginosa isolates in severe chronic obstructive pulmonary disease: characterization and risk factors. BMC Pulm Med. 2014; 14: 103.

20 Martinez-Solano L, Macia MD, Fajardo A, Oliver A, Martinez JL. Chronic Pseudomonas aeruginosa infection in chronic obstructive pulmonary disease. Clin Infect Dis. 2008; 47: 1526-33.

21 Pauwels RA, Buist AS, Calverley PM, Jenkins CR, Hurd SS. Global strategy for the diagnosis, management, and prevention of chronic obstructive pulmonary disease.

NHLBI/WHO Global Initiative for chronic obstructive lung disease (GOLD) Workshop summary. Am J Respir Crit Care Med. 2001; 163: 1256-76.

22 Johnson GR, Knibbs LD, Kidd TJ, Wainwright CE, Wood ME, Ramsay KA, Bell SC, Morawska L. A novel method and its application to measuring pathogen decay in bioaerosols from patients with respiratory disease. PLoS One. 2016; 11: e 0158763.

23 Miller MR, Hankinson J, Brusasco V, Burgos F, Casaburi R, Coates A, Crapo R, Enright P, van der Grinten CP, Gustafsson P, Jensen R, Johnson DC, MacIntyre N, McKay R, Navajas D, Pedersen OF, Pellegrino R, Viegi G, Wanger J. Standardisation of spirometry. Eur Respir J. 2005; 26: 319-38.

24 Stanojevic S, Wade A, Stocks J, Hankinson J, Coates AL, Pan H, Rosenthal M, Corey M, Lebecque P, Cole TJ. Reference ranges for spirometry across all ages: a new approach. Am J Respir Crit Care Med. 2008; 177: 253-60.

25 Anuj SN, Whiley DM, Kidd TJ, Bell SC, Wainwright CE, Nissen MD, Sloots TP. Identification of Pseudomonas aeruginosa by a duplex real-time polymerase chain reaction assay targeting the ecf $X$ and the $g y r B$ genes. Diagn Microbiol Infect Dis. 2009; 63: 127-31. 26 Jones-Lopez EC, Namugga O, Mumbowa F, Ssebidandi M, Mbabazi O, Moine S, Mboowa G, Fox MP, Reilly N, Ayakaka I, Kim S, Okwera A, Joloba M, Fennelly KP. Cough aerosols of Mycobacterium tuberculosis predict new infection: a household contact study. Am J Respir Crit Care Med. 2013; 187: 1007-15.

27 Macher JM. Positive-hole correction of multiple-jet impactors for collecting viable microorganisms. Am Ind Hyg Assoc J. 1989; 50: 561-8.

28 Syrmis MW, Kidd TJ, Moser RJ, Ramsay KA, Gibson KM, Anuj S, Bell SC, Wainwright CE, Grimwood K, Nissen M, Sloots TP, Whiley DM. A comparison of two informative SNP-based strategies for typing Pseudomonas aeruginosa isolates from patients with cystic fibrosis. BMC Infect Dis. 2014; 14: 307.

29 Syrmis MW, Carroll MR, Sloots TP, Coulter C, Wainwright CE, Bell SC, Nissen MD. Rapid genotyping of Pseudomonas aeruginosa isolates harboured by adult and paediatric patients with cystic fibrosis using repetitive-element-based PCR assays. J Med Microbiol. 2004; 53: 1089-96.

30 Navaratnam V, Forrester DL, Eg KP, Chang AB. Paediatric and adult bronchiectasis: Monitoring, cross-infection, role of multidisciplinary teams and self-management plans. Respirology. 2019; 24: 115-26.

31 Wood ME, Stockwell RE, Johnson GR, Ramsay KA, Sherrard LJ, Jabbour N, Ballard E, O'Rourke P, Kidd TJ, Wainwright CE, Knibbs LD, Sly PD, Morawska L, Bell SC. Face 
masks and cough etiquette reduce the cough aerosol concentration of Pseudomonas aeruginosa in people with cystic fibrosis. Am J Respir Crit Care Med. 2018; 197: 348-55. 32 Stockwell RE, Wood ME, He C, Sherrard LJ, Ballard EL, Kidd TJ, Johnson GR, Knibbs LD, Morawska L, Bell SC. Face Masks Reduce the Release of Pseudomonas aeruginosa Cough Aerosols When Worn for Clinically Relevant Periods. Am J Respir Crit Care Med. 2018; 198: 1339-42.

33 Kidd TJ, Ramsay KA, Hu H, Marks GB, Wainwright CE, Bye PT, Elkins MR, Robinson PJ, Rose BR, Wilson JW, Grimwood K, Bell SC. Shared Pseudomonas aeruginosa genotypes are common in Australian cystic fibrosis centres. Eur Respir J. 2013; 41: 1091100 .

34 Ranganathan SC, Skoric B, Ramsay KA, Carzino R, Gibson AM, Hart E, Harrison J, Bell SC, Kidd TJ. Geographical differences in first acquisition of Pseudomonas aeruginosa in cystic fibrosis. Ann Am Thorac Soc. 2013; 10: 108-14.

35 Valderrey AD, Pozuelo MJ, Jimenez PA, Macia MD, Oliver A, Rotger R. Chronic colonization by Pseudomonas aeruginosa of patients with obstructive lung diseases: cystic fibrosis, bronchiectasis, and chronic obstructive pulmonary disease. Diagn Microbiol Infect Dis. 2010; 68: 20-7.

36 Flume PA, Chalmers JD, Olivier KN. Advances in bronchiectasis: endotyping, genetics, microbiome, and disease heterogeneity. Lancet. 2018; 392: 880-90.

37 Chalmers JD, Aliberti S, Filonenko A, Shteinberg M, Goeminne PC, Hill AT, Fardon TC, Obradovic D, Gerlinger C, Sotgiu G, Operschall E, Rutherford RM, Dimakou K, Polverino E, De Soyza A, McDonnell MJ. Characterisation of the "frequent exacerbator phenotype" in bronchiectasis. Am J Respir Crit Care Med. 2018; 10.1164/rccm.2017112202OC.

38 Borekci S, Halis AN, Aygun G, Musellim B. Bacterial colonization and associated factors in patients with bronchiectasis. Ann Thorac Med. 2016; 11: 55-9.

39 Jacobs DM, Ochs-Balcom HM, Zhao J, Murphy TF, Sethi S. Lower airway bacterial colonization patterns and species-specific interactions in chronic obstructive pulmonary disease. J Clin Microbiol. 2018; 10.1128/jcm.00330-18.

40 Sethi S, Murphy TF. Infection in the pathogenesis and course of chronic obstructive pulmonary disease. N Engl J Med. 2008; 359: 2355-65.

41 Ridderberg W, Andersen C, Vaeth M, Bregnballe V, Norskov-Lauritsen N, Schiotz PO. Lack of evidence of increased risk of bacterial transmission during cystic fibrosis educational programmes. J Cyst Fibros. 2016; 15: 109-15.

42 Wainwright CE, France MW, O'Rourke P, Anuj S, Kidd TJ, Nissen MD, Sloots TP, Coulter C, Ristovski Z, Hargreaves M, Rose BR, Harbour C, Bell SC, Fennelly KP. Coughgenerated aerosols of Pseudomonas aeruginosa and other Gram-negative bacteria from patients with cystic fibrosis. Thorax. 2009; 64: 926-31. 